\title{
PEMANFAATAN PELAYANAN KESEHATAN DAN PENGGUNAAN AIR SUNGAI DENGAN KELUHAN KESEHATAN KULIT PADA MASYARAKAT
}

\author{
UTILIZATION OF HEALTH SERVICES AND USE OF RIVER WATER WITH COMPETI- \\ TION HEALTH COMPLAINT IN THE COMMUNITY
}

\author{
Yeni Riza $^{1}$, Fahrurazi $^{2}$, Erwin Ernadi ${ }^{3}$ \\ ${ }^{1,2,3}$ Fakultas Kesehatan Masyarakat UNISKA Banjarmasin \\ Email Korespondensi : \\ yeniriza86@gmail.com \\ fahrurazi.fkm@gmail.com \\ ererwin3@gmail.com
}

\begin{abstract}
Abstrak
Hasil pemantauan kualitas air sungai oleh Badan Lingkungan Hidup Kota Banjarmasin tahun 2013, 2014, dan 2015 diperoleh hasil bahwa Sungai Martapura dan Sungai Barito termasuk dalam status cemar berat. Tujuan penelitian ini adalah untuk mengetahui pemanfaatan pelayanan kesehatan dan penggunaan air sungai dengan keluhan kesehatan kulit pada masyarakat sekitar sungai Pangambangan Banjarmasin. Target penelitian ini diharapkan dapat dilakukan pengabdian kepada masyarakat di sekitar sungai pengambangan Banjarmasin agar masyarakat dapat lebih meningkatkan pengetahuan, sikap dan tindakannya terhadap hidup sehat dan mampu memanfaatkan pelayanan kesehatan, khususnya Puskesmas terdekat. Metode penelitian yang digunakan deskriptif dengan pendekatan cross sectional. Sampel dilakukan secara purposive sampling yaitu pengambilan sampel dengan tidak memberikan peluang yang sama dari setiap anggota populasi. Instrumen penelitian ini menggunakan kuesioner dengan teknik wawancara. Analisa data menggunakan uji statistik Chi Square. Hasil penelitian menunjukkan bahwa sebagian besar masyarakat tidak menggunakan pelayanan kesehatan yaitu 79 responden $(85,87 \%)$, sebagian besar masyarakat tidak mengalami keluhan kesehatan kulit yaitu sebesar 89 responden (96,7\%). Dalam penggunaan air sungai diperoleh hasil bahwa lebih banyak responden dalam kategori menggunakan air sungai yaitu 76 responden (82,61\%). Hasil uji chi square menunjukkan bahwa ada hubungan antara pemanfaatan layanan kesehatan dengan keluhan kesehatan kulit $(p$-value $=0,000)$ dan tidak ada hubungan antara penggunaan air sungai dengan keluhan kesehatan kulit $p$-value $=0,130$ )
\end{abstract}

Kata Kunci : Pemanfaatan, Pelayanan Kesehatan, Sungai

\begin{abstract}
The results of river water quality monitoring from 2013 to 2015 resulted that the Martapura River and Barito River included in severe pollutant status. The purpose of this study is to know the utilization of health services and use of river waterwith skin health complaints by communities around the Banjarmasin Pangambangan river. The target of this research is expected to be continued to be service to the people around Pangambangan Banjarmasin river so that people have awareness, willingness, and ability in utilizing health services, especially the nearest public health center. The research method used is descriptive with cross sectional approach. The sample is done by purposive sampling that is sampling by not giving equal opportunity from every member of population. The instrument in this research is using questionnaire with interview technique. Analysis of this data using Chi Square statistical test with the help of computerization Mean value (a) 0.05 with confidence value 0.95 . The result of the research shows that most of society do not use health service that is 79 responden $(85,87 \%)$, most of society do not experience skin health complaint that is 89 responden (96,7\%). In the use of river water obtained results that more respondents in the category using river water that is 76 respondents $(82.61 \%)$. The result of chi square test showed that there was a correlation between health service utilization with skin health complaint $(p$-Value $=0,000)$ and there is no relationship between river water use with skin health complaint p-value $=0,130$ )
\end{abstract}

Keywords: Utilization, Health Services, River 


\section{PENDAHULUAN}

Hasil pemantauan kualitas air sungai oleh Badan Lingkungan Hidup Kota Banjarmasin tahun 2013, 2014, dan 2015 diperoleh hasil bahwa Sungai Martapura dan Sungai Barito termasuk dalam status cemar berat. Tahun 2015 tim pemantauan Air Badan Lingkungan Kota Banjarmasin telah memantau sebagian Sungai Barito yang merupakan sungai lintas kota dan provinsi atau disebut sebagai sungai utama, dan sebagian Sungai Martapura yang merupakan sungai lalu lintas kabupaten/kota dan merupakan sungai strategis dimana sebagian segi tersebut termasuk dalam wilayah kota Banjarmasin. Sungai tersebut sangat penting keberadaanya untuk menunjang kebutuhan hidup sehari-hari masyarakat sekitarnya dan merupakan bahan baku PDAM.

Secara epidemiologis ada keterkaitan yang erat antara masalah air bersih dengan penyakit kulit, maka oleh sebab itu dengan adanya tingkat cakupan air bersih yang tinggi dapat menurunkan angka penyakit kulit. Dalam kaitan dengan hal tersebut maka seharusnya air bersih yang digunakan harus memenuhi persyaratan kualitas yang telah tetapkan. Persyaratan kualitas tersebut telah tertuang dalam Permenkes No 492/2010 tentang syarat-syarat dan kualitas air bersih. ${ }^{2}$

Perilaku masyarakat merupakan salah satu faktor utama dalam pemilihan air bersih yang sesuai persyaratan kualitas yang telah ditetapkan. Menurut Montano, (2008) Integrated Behavioral Model (IBM) merupakan teori perilaku kesehatan yang berfokus pada individu yang merupakan sasaran paling penting dalam perubahan perilaku yang diharapkan sehingga informasi mengenai peran individu dalam perubahan perilaku sangat diperlukan untuk menyusun rencana intervensi. IBM menekankan pentingnya niat sebagai motivasi untuk berperilaku. Perilaku tertentu paling mungkin terjadi jika seseorang memiliki niat kuat untuk melakukan, memiliki pengetahuan serta keterampilan untuk melakukannya, tidak ada kendala lingkungan yang serius menghalangi, perilaku tersebut diyakini penting, dan orang tersebut telah melakukan perilaku sebelumnya sebagai kebiasaan. ${ }^{8}$

Berdasarkan survei pendahuluan, sebagian besar masyarakat Pangambangan menggunakan air sungai untuk mandi, mencuci pakaian maupun peralatan dapur, buang air besar/kecil, termasuk mencuci kendaraan bermotornya. Hal ini dikarenakan kebiasaan yang sudah turun temurun dan mereka menganggap sudah kebal terhadap penyakit yang diakibatkan oleh penggunaan air sungai, padahal seluruh masyarakatnya sudah mengetahui bahwa air sungai yang mereka gunakan sudah tercemar berat dan tidak layak untuk digunakan. Walaupun demikian, masyarakat tetap memanfaatkan air sungai tersebut. Sesuai dengan pendapat Setiawan (2009), ada beberapa alasan yang menyebabkan masyarakat membuang sampah ke sungai. Di antaranya, membuang sampah ke sungai dinilai lebih praktis dan gratis, kurangnya sarana tempat membuang sampah di sekitar sungai dan sudah menjadi budaya. ${ }^{13}$

Masyarakat berpendapat bahwa air sungai yang mereka gunakan sering pasang surut dan mengalir sehingga kuman, virus, dan bakteri yang ada disungai su- dah larut dan tidak mempengaruhi kesehatan. Penyakit kulit yang dialami oleh masyarakat Kelurahan Pangambangan sungai berupa gatal, bintik-bintik merah ,nyeri, panas/ hangat, kulit bersisik, namun tidak tertutup kemungkinan hanya disebabkan oleh penggunaan air bersih saja, tetapi terdapat kemungkinan-kemungkinan lain seperti alergi makanan, kekurangan gizi, sanitasi lingkungan dan kesehatan perorangan. Salah satu upaya penanggulangan penyakit kulit oleh masyarakat ini adalah dengan memanfaatkan pelayanan kesehatan terdekat, seperti puskesmas, klinik kesehatan atau rumah sakit. Pemanfaatan pelayanan kesehatan adalah hasil dari proses pencarian pelayanan kesehatan oleh seseorang maupun kelompok. Menurut Notoatmodjo (2007), perilaku pencari pengobatan adalah perilaku individu maupun kelompok atau penduduk untuk melakukan atau mencari pengobatan. Perilaku pencarian pengobatan di masyarakat terutama di Negara sedang berkembang sangat bervariasi. $^{14}$

Perilaku dan kebiasaan-kebiasaan masyarakat yang kurang memahami baik tentang sanitasi terutama dalam hal penyediaan dan penggunaan air bersih dapat menurunkan derajat kesehatan masyarakat itu sendiri sehingga dapat menimbulkan terjadinya penyakit kulit. Dari data Dinas Kesehatan Kota Banjarmasin tahun 2015, kasus penyakit kulit di wilayah kerja Puskesmas 9 November yaitu sebanyak $1.267 .^{3}$ Oleh karena itu, maka penulis meneliti "Pemanfaatan Pelayanan Kesehatan dan Penggunaan Air Sungai Dengan Keluhan Kesehatan Kulit Pada Masyarakat Sekitar Sungai Pangambangan Kota Banjarmasin”

\section{METODE}

Penelitian ini menggunakan metode survey Analitik dengan rancangan penelitian yaitu Cross Sectional. Penelitan ini dilaksanakan pada bulan Mei-September 2017. Populasi dalam penelitian ini adalah semua masyarakat di sekitar sungai Pangambangan yang berkunjung dan berobat di Puskesmas 9 November dengan keluhan kesehatan kulit dengan jumlah 1.267. dengan jumlah sampel sebanyak 92 responden (kepala keluarga yang mempunyai keluhan kesehatan kulit) yang diambil dengan menggunakan rumus Slovin, dengan teknik non random (non probability) sampling. Instrumen penlitian menggunakan kuesioner dengan metode wawancara. Analisis data dalam penelitian ini menggunakan uji chi square.

\section{HASIL}

Hasil penelitian pada tabel 1 menunjukkan pemanfaatan pelayanan kesehatan menunjukan bahwa 79 responden yang tidak memanfaatkan pelayanan kesehatan, yang tidak mengalami keluhan kesehatan kulit sebanyak 79 orang $(100 \%)$, dan tidak ada yang mengalami keluhan kesehatan kulit, sedangkan 13 responden yang memanfaatkan pelayanan kesehatan, yang tidak mengalami keluhan kesehatan kulit yaitu sebanyak 10 orang $(76,9 \%)$, dan yang mengalami keluhan kesehatan kulit yaitu sebanyak 3 orang $(23,1 \%)$. Diperoleh Hasil uji statistik dengan nilai $p$ Value $=0,000$ nilai $\mathrm{P}<(\alpha=0,05)$, hal ini berarti Ha 
diterima dan Ho ditolak atau ada hubungan antara pemanfaatan Pelayanan Kesehatan dengan keluhan kesehatan kulit. dibuktikan dan hasil program pembangunan kesehatan di beberapa negara berkembang tidak memuaskan. Kegagalan pemanfaatan pelayanan sering dituduhkan pada

Tabel 1 Hubungan Pemanfaatan Pelayanan Kesehatan dengan Keluhan Kesehatan Kulit pada Masyarakat

\begin{tabular}{|c|c|c|c|c|c|c|c|}
\hline \multirow{2}{*}{$\begin{array}{l}\text { Pemanfaatan } \\
\text { Pelayanan } \\
\text { Kesehetan }\end{array}$} & \multicolumn{4}{|c|}{ Keluhan Kesehatan Kulit } & \multirow[b]{2}{*}{ Jumlah } & \multirow[b]{2}{*}{$\%$} & \multirow[b]{2}{*}{ P Valuc } \\
\hline & $\overline{Y a}$ & $\%$ & Tidak & $\%$ & & & \\
\hline $\mathrm{Ya}$ & 0 & 0 & 79 & 100 & 79 & 100 & \multirow{3}{*}{0,000} \\
\hline Tidak & 3 & 23,1 & 10 & 76,9 & 13 & 100 & \\
\hline Jumlah & 3 & 3,3 & 89 & 96,7 & 92 & 100 & \\
\hline
\end{tabular}

Sumber: Data Primer 2017

Tabel 2 Hubungan Penggunaan Air Sungai dengan Keluhan Kesehatan Kulit pada Masyarakat

\begin{tabular}{|c|c|c|c|c|c|c|c|}
\hline \multirow[b]{2}{*}{ Penggunaan Air Sungai } & \multicolumn{4}{|c|}{ Keluhan Kesehatan Kulit } & \multirow{2}{*}{$\begin{array}{c}\text { Jumla } \\
\text { h }\end{array}$} & \multirow[b]{2}{*}{$\%$} & \multirow[b]{2}{*}{$P$ Value } \\
\hline & $\mathrm{Ya}$ & $\%$ & Tidak & $\%$ & & & \\
\hline Menggunakan air sungai & 1 & 1,3 & 75 & 98,7 & 76 & 100 & \\
\hline $\begin{array}{c}\text { Tidak menggunakan air } \\
\text { sungai }\end{array}$ & 2 & 12,5 & 14 & 87,5 & 16 & 100 & 0,130 \\
\hline Jumlah & 3 & 3,3 & 89 & 96,7 & 92 & 100 & \\
\hline
\end{tabular}

Sumber: Data Primer 2017

Tabel 2 menampilkan penggunaan air sungai menunjukan dari 76 responden menggunakan air sungai, yang tidak mengalami keluhan kesehatan kulit sebanyak 75 orang $(98,7 \%)$, dan yang mengalami keluhan kesehatan kulit yaitu sebanyak 1 orang $(1,3 \%)$, sedangkan 16 responden tidak menggunakan air sungai, yang tidak mengalami keluhan kesehatan kulit yaitu sebanyak 14 orang $(87,5 \%)$, dan yang mengalami keluhan kesehatan kulit yaitu sebanyak 2 orang (12,5\%). Hasil uji statistic diperoleh nilai $p$-value 0,130 nilai $\mathrm{P}>$ $(\alpha=0,05)$, hal ini berarti Ha ditolak dan Ho diterima atau tidak ada hubungan antara tindakan masyarakat dalam penggunaan air sungai dengan keluhan kesehatan kulit.

\section{PEMBAHASAN}

Pemanfaatan pelayanan Puskesmas dipengaruhi oleh beberapa faktor antara lain persepsi masyarakat tentang kesehatan, persepsi masyarakat tentang kualitas pelayanan, pendapatan keluarga dan tingkat pendidikan. Dalam penelitian ini peneliti menememukan data karakteristik pendidikan masyarakat di sekitar sungai Pangambangan sebagian besar pendidikan SD/ MI, karakteristik pekerjaan responden, yang mana sebagian besar masyarakat di sekitar sungai Pangambangan adalah memiliki pekerjaan sebagai pedangan dan buruh.

Kurangnya akses sebagian penduduk terutama di daerah yang miskin atau terpencil merupakan sebab utama mengapa pelayanan yang ditawarkan tidak cukup dimanfaatkan. ${ }^{4}$ Kurangnya perhatian pada aspek kebutuhan pemakai jasa pelayanan kesehatan tidak dapat masyarakat pemakai jasa layanan, pada kepercayaannya, adat-istiadat atau kemiskinannya. Beberapa studi Lasker, 1981 justru menyebutkan bahwa pelayanan yang diberikan tidak cukup sensitif dengan kebutuhan mereka. Oleh karena itu, kualitas pelayanan (quality of care) merupakan determinan penting yang mempengaruhi pemanfaatan pelayanan. ${ }^{4}$ Dalam penelitian ini sebagian besar responden tidak memilih pelayanan kesehatan yaitu puskesmas terdekat dalam upaya peningkatan kesehatannya, dimana sebagian masyarakat yang tidak memanfaatkan pelayanan kesehatan lebih cendrung suka berobat ke mantri kesehatan, bahkan ada juga yang hanya mengandalkan jasa urut saja ketika mereka mengalami keluhan kesehatan.

Berbeda dengan variabel pemanfaatan pelayan kesehatan, pada variabel penggunaan air sungai tidak ada hubungan dengan keluhan kesehatan kulit pada masyarakat sekitar sungai pangambangan. Menurut Notoadmodjo (2010), sikap adalah kecenderungan untuk bertindak (praktik). Sikap belum tentu terwujud dalam tindakan perlu faktor lain, yaitu antara lain adanya fasilitas atau sarana dan prasarana. Praktik atau tindakan ini dapat dibedakan menjadi tiga tingkatan menurut kualitasnya, yaitu praktik terpimpin (guided response) apabila subjek atau seseorang telah melakukan sesuatu tetapi masih tergantung pada tuntutan atau menggunakan panduan, praktik secara mekanisme (mechanism) apabila subjek atau seseorang telah melakukan sesuatu hal secara otomatis maka disebut praktik atau tindakan 
mekanis, dan adopsi (adoption) adalah suatu tindakan atau praktik yang sudah berkembang. Artinya apa yang dilakukan tidak sekedar rutinitas atau mekanisme saja, tetapi sudah dilakukan modifikasi, atau tindakan atau perilaku yang yang berkualitas. ${ }^{6}$

Dari hasil penelitian, dapat diketahui bahwa masyarakat yang menggunakan air sungai sebagai kebutuhan sehari-hari merupakan tindakan yang dapat mencemari sungai terutama dalam hal limbah domestik. Limbah domestik yang dibuang pada badan sungai mengandung sampah padat berupa tinja dan cair berupa sampah rumah tangga dan beberapa sifat utama, antara lain mengandung bakteri, yang dapat menyebabkan penularan penyakit, mengandung bahan organic dan padatan tersupensi sehingga BOD biasanya tinggi, mengandung padatan organik dan anorganik yang mengendap di dasar perairan dan menyebabkan DO rendah, mengandung bahan terapung dalam bentuk suspense sehingga mengurangi kenyamanan dan menghambat laju fotosintesis.

Secara umum dapat dikatakan bahwa masyarakat pengguna air sungai pangambangan melakukan tindakan pencemaran sungai. Kebiasaan mandi bagi masyarakat di sekitar sungai pangambangan. juga ada kesamaan dengan mencuci dan melakukan kegiatan rumah tangga lainnya disungai. Satu hal yang dapat mengubah kegiatan masyarakat ini yaitu jika air asin dimusim kemarau yang dialami masyarakat sekitar sungai Pengambangan. Hasil survei menunjukkan bahwa masyarakat juga menggunakan air sungai sebagai tempat sampah dikarenakan tidak adanya tempat pembuangan sementara yang dekat dari tempat tinggal, tidak ada petugas kebersihan yang datang untuk membawa sampah yang telah dikumpulkan sehingga masyarakat lebih memilih membuang sampah kesungai. Selain itu, banyak masyarakat yang kesulitan untuk membayar PDAM setiap bulannya dikarenakan sebagian besar masyarakat hanya pedagang yang hasil pendapatan mereka setiap bulan tidak memeuhi kebutuhan seharihari mereka, apalagi untuk membayar PDAM sehingga mereka lebih memilih menggunakan air sungai untuk keperluan sehari-hari selain untuk minum karena air sungai sangat berguna dan dapat menurunkan pengeluaran mereka setiap bulannya. Hal ini sejalan dengan hasil penelitian Hutagaol (2010), menunjukkan bahwa tindakan penggunaan air sungai responden dalam kategori baik hanya $2,2 \%$, selebihnya pada kategori sedang sebesar $68,1 \%$ dan kategori buruk $29,7 \%$. Hal ini menunjukkan bahwa pengetahuan yang masih kurang mengenai penggunaan air sungai menyebabkan masih ada masyarakat yang memiliki tindakan yang kurang baik dalam penggunaan air sungai dimana juga terdapat $78 \%$ responden mengalami keluhan kesehatan kulit. ${ }^{9}$ Menurut Budiharto (2010) perilaku kesehatan dipengaruhi oleh faktor internal meliputi pengetahuan, persepsi, emosi, motivasi, edangkan faktor eksternal meliputi lingkungan fisik maupun non fisik. ${ }^{11}$

Penelitian ini sejalan dengan penelitian Menurut Suryadi (2014) tentang "Perilaku Masyarakat dalam Memanfaatkan Air Sungai Siak sebagai Sumber Kehidupan dan Dampaknya terhadap Estetika serta Kesehatan Lingkungan di Wilayah Waterfront City Pek- anbaru" menunjukkan bahwa Perilaku masyarakat sungai siak dikategorikan buruk yang terlihat dari dampaknya pada sungai yang dijadikan tempat buangan limbah domestik (rumah tangga). ${ }^{7}$ Faktor yang mempengaruhi perilaku masyarakat ini dikarenakan oleh faktor kebiasaan, tingkat ekonomi rendah dan kenyamanan. Dampak dari perilaku masyarakat ini berupa timbulnya penyakit kulit dan diare akibat dari meningkatnya bakteri E. coli, sedangkan dampak terhadap estetika lingkungan berupa penampilan air yang buruk, bau tidak sedap dan polusi visual (estetika pemandangan yang buruk) sekitar perairan. ${ }^{8}$ Penelitian yang dilakukan oleh Kurniasih,dkk 2015 tentang faktor yang berhubungan dengan kejadian gangguan kulit pada masyarakat di Desa Puguk Kecamatan Sungai Ambawang Kabupaten Kubu Raya menunjukkan adanya hubungan antara jarak perendaman karet $(p$-value $=0,000 ; P R=3,847)$, banyak rendaman karet ( $\mathrm{p}$-value $=0,001 ; \mathrm{PR}=2,572)$ dengan kejadian gangguan kulit. tetapi tidak terdapat hubungan antara frekuensi mandi ( $\mathrm{p}$-value $=0,279$ ), jumlah air untuk mandi ( $\mathrm{p}$ value $=0,618$ ) dan lama tinggal $(\mathrm{p}$ value $=0,938) .{ }^{10}$ Begitu juga dengan penelitian Raksanagara (2017), menunjukkan perilaku menggunakan air bersih berbeda pada ketiga kelompok responden berdasar atas jenis sumber air bersih yang digunakan. Pada responden PDAM dan ST termasuk perilaku dengan kategori cukup dan responden STT termasuk perilaku dengan kategori buruk. ${ }^{8}$

\section{KESIMPULAN}

Penelitian ini menyimpulkan bahwa pemanfaatan pelayanan kesehatan pada masyarakat disekitar sungai tergolong rendah, sebagian besar masyarakat di sekitar sungai Pangambangan menggunakan air sungai untuk kebutuhan seharihari, dan keluhan kesehatan kulit pada masyarakat lebih bnayak yang tidak mengalami keluhan kesehatan kulit. Pemanfaatan pelayanan kesehatan berhubungan secara bermakna dengan keluhan kesehatan kulit dan tidak ada hubungan antara penggunaan air sungai dengan keluhan kesehatan kulit.

\section{UCAPAN TERIMA KASIH}

Peneliti mengucapkan terima kasih atas kepada Rektor Universitas Islam Kalimantan, Ketua LP2M Universitas Islam Kalimantan, Dekan FKM Universitas Islam Kalimantan, dosen-dosen di FKM Universitas Islam Kalimantan, warga masyarkat sekitar sungai Pangambangan Banjarmasin.

\section{DAFTAR PUSTAKA}

1. Badan Lingkungan Hidup. (2015). Data Data Kuliatas Air Banjrmasin Tahun 2015. Badan Lingkungan Hidup Banjarmasin. Banjarmasin

2. Depkes RI. (2010). Permenkes RI No. 492/ MENKES/PER/IV/2010. Tentang Persyaratan Kualitas Air Minum. Depkes RI, Jakarta.

3. Puskesmas 9 November, 2015. Laporan Tahunan Puskesmas 9 November. Banjarmasin : Puskesmas 9 November

4. Tukiran, T 1996. Pemanfaatan Pelayanan Kesehatan dan Keluarga Berencana di Daerah Transmigrasi di 
Sulawesi Tenggara. Jurnal Kependudukan dan Kebijakan UGM. Diakses tanggal 10 Juli 2017

5. Notoatmodjo, Soekidjo, 2010. Ilmu Perilaku Kesehatan. Jakarta: Rineka Cipta

6. Supriharyono, 2002. Pelestarian Sumber Daya Tanah dan Air. Yogyakarta: Andi Offset

7. Suryadi, Thamrin, Murad 2014. Perilaku Masyarakat dalam Memanfaatkan Air Sungai Siak sebagai Sumber Kehidupan dan Dampaknya terhadap Estetika serta Kesehatan Lingkungan di Wilayah Waterfront City Pekanbaru. Jurnal Dinamika Lingkungan Indonesia, Juli 2016, p 100-106 Diakses tanggal 10 Juli 2017

8. Raksanagara, Santanu, Sari 2017. Faktor yang Memengaruhi Perilaku Penggunaan Air Bersih pada Masyarakat Kumuh Perkotaan berdasar atas Integrated Behavior Model. E-Journal Faculty of Medicine Universitas Padjajaran. Diakses tanggal 3 September 2017

9. Hutagaol Elfrida (2010). Perilaku Masyarakat Dalam Penggunaan Air Sungai Lau Gerbong Dan Keluhan Kesehatan Kulit Di Desa Perbesi Kecamatan Tiga Binanga Kabupaten Karo Tahun 2010. Available from: https:/www.researchgate.net/ publica-

tion/45589495_Perilaku_Masyarakat_Dalam_Pengg unaan_Air_Sungai_Lau_Gerbong_Dan_Keluhan_K esehatan_Kulit_Di_Desā_Perbesi_Kecamatan_Tīga Binanga Kabüpaten Käro Tahun 2010 [accessed $\bar{D}$ ec 27 2017].

10. Kurniasih Eva, dkk (2015). Faktor yang berhubungan dengan kejadian gangguan kulit pada masyarakat di Desa Puguk Kecamatan Sungai Ambawang Kabupaten Kubu Raya. http:// repository.unmuhpnk.ac.id/312/1/JURNAL.pdf. [accessed Dec 27 2017].

11. Budiharto. Pengantar ilmu perilaku kesehatan dan pendidikan kesehatan gigi. Jakarta: EGC; 2010. h. 17-21

12. Daniel E, Montano DK. Theory of reasoned action, theory of planned behavior and the integrated behavioral model. Dalam: Karen Glanz BKR, Viswanath $\mathrm{K}$, penyunting. Health behavior and health education theory, research and practice. Edisi ke-4. San Francisco: John Wiley and Sons; 2008. hlm. 67 $-92$.

13. Setiawan, H. 2009. Sungai MartapuraSumber Kehidupan. http://sebuah blog.blogspot.com /2009/02/ sungaimartapura-sumber-kehidupan. Html. Diakses tanggal 27 Desember 2017.

14. Notoatmodjo Soekidjo (2007). Promosi Kesehatan Teori dan Ilmu Perilaku. Jakarta, Rineka Cipta

\section{Submit your next manuscript to MPPKI}

- We accept pre-submission inquiries

- Our selector tool helps you to find the most relevant journal

- We provide round the clock customer support

- Convenient online submission

- Maximum visibility for your research

Submit your manuscript at

IMPसाPुण Wedli Prallor

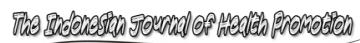

